\title{
BONES MINERALIZATION STATUS OF SOLDIERS DOING MILITARY SERVICE IN DIFFERENT TYPES OF POLISH ARMY UNITS
}

\section{STAN MINERALIZACJI KOŚCI ŻOŁNIERZY PEŁNIACYCH SŁUŻBE W RÓŻNYCH TYPACH JEDNOSTEK WOJSKA POLSKIEGO}

\author{
Jerzy Bertrandt ${ }^{1,2(A, B, C, D, E, F, G)}$, Anna Kłos ${ }^{2(B, C, D, E, F)}$ \\ ${ }^{1}$ Pope John Paul II State School of Higher Education in Biała Podlaska, \\ Faculty of Economics and Technical Sciences, Department of National Security, Poland \\ ${ }^{2}$ Military Institute of Hygiene and Epidemiology, Department of Hygiene and Physiology, Poland
}

Authors' contribution Wkład autorów:

A. Study design/planning zaplanowanie badań

B. Data collection/entry zebranie danych

C. Data analysis/statistics dane - analiza i statystyki D. Data interpretation interpretacja danych E. Preparation of manuscript przygotowanie artykułu F. Literature analysis/search wyszukiwanie i analiza literatury G. Funds collection zebranie funduszy
Tables: 2

Figures: 0

References: 14

Submitted: 21.01.2016

Accepted: 16.02.2016

\section{Summary}

Background. For proper construction and functioning of human skeletal system a very important thing is adequate supply of calcium, which content in daily rations, in addition to genetics, degree of physical activity and level of sex steroids, is an essential factor influencing on bone mass. Aim of the work: the aim of the work was to assess mineral status of regular soldiers doing military service in different types of Polish military units.

Material and methods. An assessment of bones calcification and protein-energy nutritional status of 1913 men, soldiers doing military service in different types of Polish military units, was made. Body height and body mass were determined by standard methods using a scales and a height-meter. Bone mineral density was measured by DEXA densitometry on forearm bone of non-prevailing arm, using the EXA 3000 apparatus.

Results. Results of densitometry showed that 1594 soldiers, that is $83.3 \%$ of subjects had standard bone calcification. Bone mineralization characteristic of osteopenia was found among 304 people, that is $15.9 \%$ of examined, while 15 subjects $(0.8 \%)$ revealed changes characteristic of osteoporosis.

\section{Conclusions.}

1. Bone mineral density of $16.7 \%$ of examined soldiers serving in different types of military units indicates presence of abnormalities in bone calcification with varying degrees of severity.

2. It is advisable to take among soldiers an extensive health promotion regarding dietary health education aimed at nutritional prevention of bone mineralization disorders can cause fractures and early elimination soldiers from service.

Keywords: mineral nutritional status, bone calcification, soldiers

\section{Streszczenie}

Wstęp. Dla prawidłowej budowy i funkcjonowania układu kostnego człowieka bardzo ważną rzeczą jest odpowiednia podaż wapnia, którego zawartość w całodziennej racji pokarmowej, obok uwarunkowań genetycznych, stopnia aktywności fizycznej i poziomu hormonów płciowych, stanowi zasadniczy czynnik wpły wający na wartość masy kostnej w organizmie. Celem pracy była ocena stanu odżywienia mineralnego żołnierzy pełniących zawodową służbę wojskową w różnych typach jednostek wojskowych Wojska Polskiego.

Materiał i metoda. Dokonano oceny stanu uwapnienia kości oraz odżywienia białkowoenergetycznego 1913 mężczyzn, żołnierzy, pełniących służbę w różnych typach jednostek wojskowych. Wysokość i masę ciała określano standardowymi metodami przy użyciu wagi i wzrostomierza. Gęstość mineralną kości mierzono metodą densytometryczną DEXA, na kości przedramienia ręki niedominującej, przy użyciu aparatu EXA 3000.

Wyniki. Wyniki badań densytometrycznych wykazały, że 1594 żołnierzy, czyli 83,3\% badanych miało uwapnienie kości w normie. Mineralizacje kości charakterystyczną dla osteopenii stwierdzono u 304 osób, czyli u 15,9\% badanych, podczas gdy u 15 badanych $(0,8 \%)$ wykazano zmiany charakterystyczne dla osteoporozy.

Wnioski. Stan gęstości mineralnej kości 16,7\% badanych żołnierzy pełniących służbe $\mathrm{w}$ różnych typach jednostek wojskowych wskazuje na występowanie zaburzeń $\mathrm{w}$ ich uwapnieniu o różnym stopniu nasilenia. Celowym jest podjęcie, wśród żołnierzy, szeroko zakrojonej promocji zdrowia w zakresie żywieniowej oświaty zdrowotnej, mającej na celu żywieniową profilaktykę zaburzeń mineralizacji kości.

Słowa kluczowe: stan odżywienia mineralnego, uwapnienie kości, żołnierze

Bertrandt J, Klos A. Bones mineralization status of soldiers doing military service in different types of polish army units. Health Problems of Civilization. 2016; 10(3): 71-74. doi: 10.5114/hpc.2016.61361.

Address for correspondence / Adres korespondencyjny: Jerzy Bertrandt, Pope John Paul II State School of Higher Education in Biała Podlaska, Faculty of Economics and Technical Sciences, Department of National Security, Sidorska 95/97, 21-500 Biała Podlaska, Poland, e-mail: J.Bertrandt@wihe.waw.pl, phone: +48 83 344 99 64

Copyright: (C) 2016 Pope John Paul II State School of Higher Education in Biała Podlaska. This is an Open Access journal, all articles are distributed under the terms of the Creative Commons Attribution-NonCommercial-ShareAlike 4.0 International (CC BY-NC-SA 4.0) License (http://creativecommons.org/licenses/by-nc-sa/4.0/), allowing third parties to copy and redistribute the material in any medium or format and to remix, transform, and build upon the material, provided the original work is properly cited and states its license. 


\section{Background}

More than $70 \%$ of our skeleton is made of bone tissue i.e. compounds of calcium, phosphorus and magnesium. Bone mineralisation is a dynamic process in which at the same time two processes take place: resorption and osteogenesis. While resorption is a destructive process and consists in destruction of bone tissue, osteogenesis is related with bone tissue mineralisation. Both processes are equally efficient. Therefore imbalance of bone remodeling with predominance of its destruction is cause of osteoporosis and increase of bone fragility. Maximum skeleton mass, known as the peak bone mass, human body gain between 25 and 35 years old. After the age of 40 slow, about $0.3 \%$ per year, loss of calcium from bones is observed, which causes a progressive loss of bone mass [1]. Therefore, in osteoporosis prophylaxis it is very important to achieve maximum peak bone mass, which is a major prognostic factor of osteopenia or osteoporosis occurrence risk, and thus possibility of fractures in later periods of life [2]. For proper construction and functioning of human skeletal system a very important thing is adequate supply of calcium, which content in daily rations, in addition to genetics, degree of physical activity and level of sex steroids, is an essential factor influencing on bone mass. Epidemiological studies, conducted in many centers in Poland, indicate existence of numerous irregularities in nutrition manner of Polish population, including shortages of calcium in the diet. Long-lasting, negative calcium balance results in skeletal mineralization disorders manifested as development of osteopenia, and/or osteoporosis [3,4]. Analysis of distributions of daily calcium intake from the diet indicates that $73.5 \%$ of food rations of Polish males and $86.9 \%$ females is characterized by too low content of this element [5]. Therefore, it is very important to keep positive calcium balance, which will determine advantage of osteogenesis over resorption processes, in nutrition, especially, young people.

In connection with professionalization of the Polish Army and individual feeding system of soldiers, it is not possible to monitor supply of calcium from food, and therefore it seems necessary to conduct random surveys on bone mineralization, the more that such tests are not part of routine physical examinations that are obligatory in the Polish Army.

The aim of the work was to assess mineral status of regular soldiers doing military service in different types of military units.

\section{Material and methods.}

An assessment of bones calcification and protein-energy nutritional status of 1913 men, soldiers doing military service in different types of Polish military units, was made.

Body height and body mass were determined by standard methods using a scales and a height-meter. Bone mineral density was measured by DEXA densitometry on forearm bone of non-prevailing arm, using the EXA 3000 apparatus. Bone calcification was evaluated based on the T-score value, in which average value and standard deviation in a group of young adults, regardless of age, were assumed as reference values. As a norm the $\mathrm{T}$ score value up to -1 was accepted. It means that value of bone mineral density is not lower than one standard deviation below average value. The T-score value between -1 and -2.5 is characteristic for osteopenia, while the value below -2.5 for osteoporosis [6].

\section{Results}

Average age of examined soldiers amounted to $31.6 \pm 3.73$ (26.4 - 37.2). Average body mass and body height amounted to $83.9 \pm 3.7 \mathrm{~kg}(74.4-89.6 \mathrm{~kg})$ and $177.9 \pm 2.1 \mathrm{~cm}(174.2 \mathrm{~cm}-181.4 \mathrm{~cm})$ respectively. (table 1$)$

Table 1. Basic parameters characterizing examined groups of Polish Army

\begin{tabular}{|c|c|c|c|}
\hline Type of military service & Age of subjects [years] & Body height [cm] & Body mass [kg] \\
\hline Pilots & $37.2 \pm 6.4$ & $177.6 \pm 5.2$ & $86.6 \pm 10.8$ \\
\hline Board technicians & $31.9 \pm 1.8$ & $177.1 \pm 6.7$ & $87.2 \pm 12.7$ \\
\hline $\begin{array}{c}\text { Medical aircraft crew } \\
\text { doctors } \\
\text { paramedics }\end{array}$ & $35.8 \pm 2.9$ & $180.6 \pm 6.8$ & $89.6 \pm 14.7$ \\
\hline Parachutists & $35.7 \pm 5.4$ & $176.3 \pm 5.2$ & $84.3 \pm 10.4$ \\
\hline Navy sailors & $33.6 \pm 5.8$ & $175.3 \pm 4.2$ & $74.4 \pm 8.6$ \\
\hline Armoured warfare & $29.0 \pm 5.2$ & $176.3 \pm 5.7$ & $82.4 \pm 11.8$ \\
\hline
\end{tabular}




\begin{tabular}{|c|c|c|c|}
\hline Chemical troops & $27.2 \pm 3.9$ & $177.6 \pm 6.2$ & $80.9 \pm 11.5$ \\
\hline GROM - special operations forces unit & $30.0 \pm 3.4$ & $179.5 \pm 6.6$ & $85.8 \pm 10.0$ \\
\hline Soldiers going to ISAF in Afghanistan & $27.2 \pm 3.9$ & $177.6 \pm 6.2$ & $80.9 \pm 11.5$ \\
\hline Representative Battalion & $30.4 \pm 5.1$ & $180.7 \pm 4.3$ & $85.4 \pm 10.2$ \\
\hline Representative Cavalry Regiment & $26.5 \pm 4.0$ & $179.8 \pm 5.8$ & $80.4 \pm 10.4$ \\
\hline
\end{tabular}

Results of densitometry showed that 1594 soldiers, that is $83.3 \%$ of subjects had standard bone calcification. Bone mineralization characteristic of osteopenia was found among 304 people, that is $15.9 \%$ of examined, while 15 subjects $(0.8 \%)$ revealed changes characteristic of osteoporosis (table 2 ).

Table 2. Bone calcification of examined soldiers (\%) [7,8,9,10,11,12]

\begin{tabular}{|c|c|c|c|}
\hline Type of military service & $\begin{array}{c}\text { Standards bone calcifi- } \\
\text { cation } \\
\text { T score } \mathbf{z - 1}\end{array}$ & $\begin{array}{c}\text { Osteopenia } \\
\mathbf{1}<\text { T score } \mathbf{2 - 2 , 5}\end{array}$ & $\begin{array}{c}\text { Osteoporosis } \\
\text { T score }<-\mathbf{2 , 5}\end{array}$ \\
\hline Pilots & 87.6 & 12.4 & - \\
\hline Board technicians & 84.5 & 15.5 & 6.7 \\
\hline Medical aircraft crew \\
doctors \\
paramedics & 86.6 & 6.7 & - \\
\hline Parachutists & 85.7 & 14.3 & 0.8 \\
\hline Navy sailors & 98.0 & 2.0 & 1.8 \\
\hline Armoured warfare & 76.5 & 22.7 & - \\
\hline Chemical troops & 88.6 & 9.6 & - \\
\hline GROM - special operations forces unit & 92.6 & 7.4 & 1.0 \\
\hline Soldiers going to ISAF in Afghanistan & 90.9 & 9.1 & 1.0 \\
\hline Representative Battalion & 81.6 & 17.4 & 4.2 \\
\hline Representative Cavalry Regiment & 85.3 & 13.7 & 20.8 \\
\hline
\end{tabular}

\section{Discussion}

The best bone mineralization was found among parachutists and soldiers serving in a special unit "GROM" which is most likely a result of a special selection of men to serve in this type of unit. It seems that changes characteristics of osteopenia found among over $20 \%$ of examined soldiers serving in the Representative Cavalry Regiment result from too low calcium supply with the diet during adolescence period, because average age of the subjects didn't exceed 26 years. Changes in calcification of skeleton characteristic of osteoporosis were found in a small percentage of subjects. They were found mainly among medical aircraft crews.

Abnormalities in calcification of skeleton occur also among soldiers of other armies. Examination of skeletal system of British soldiers, participants of the Gulf War, revealed significant reduction of osteogenesis, what authors associated with exposure to potentially harmful conditions of service [13]. This suggestion is confirmed by results of tests carried out among Polish soldiers returning from a mission in Afghanistan, which also showed abnormalities in mineralization of bones [9]. Results of carried out in 2006 tests of 2329 US soldiers, men and women doing 12 months service in Iraq, revealed 5252 cases of fractures or dislocations. Similar examinations of 375 men and 138 women during basic training in the Israeli artillery has revealed occurrence of fractures of femoral bone and tibia much more common among women. As result of carried out studies modification of military training programs according to sex was recommended [14].

\section{Conclusions}

1. Bone mineral density of $16.7 \%$ of examined soldiers serving in different types of military units indicates presence of abnormalities in bone calcification with varying degrees of severity which can cause fractures and early elimination soldiers from service.

2. It is advisable to take among Polish soldiers an extensive health promotion regarding dietary health education aimed at nutritional prevention of bone mineralization disorders. 


\section{References:}

1. Ziemlański Ś. Normy żywienia człowieka. Fizjologiczne podstawy. Warszawa: PZWL; 2001 (in Polish).

2. Arden N. Czynniki rozwoju ryzyka osteoporozy. In: Arden N, Spector TD, Badurski J., editors. Osteoporoza aktualny stan wiedzy. Warszawa: Wydawnictwo Medyczne Borgis; 2000. p. 36-49 (in Polish).

3. Roszkowska H. Mierniki zdrowotne stosowane w epidemiologii żywieniowej. In: Gawęcki J, Roszkowski W., editors. Żywienie człowieka a zdrowie. Warszawa: Wydawnictwo Naukowe PWN; 2009. p. 68-74 (in Polish).

4. Krejpcio Z, Staniek H, Śmigiel-Papińska D, Wójciak R, Król E. Assessment of the content of calcium, phosphorus and magnesium in the daily food rations in selected groups of population. Pol J Hum Nutr Metab. 2005; 32(Suppl.1): 133-136 (in Polish).

5. Jarosz M, Respondek W. Rola żywienia i aktywności fizycznej w profilaktyce otyłości i przewlekłych chorób niezakaźnych. In: Gawęcki J, Roszkowski W., editors. Żywienie człowieka a zdrowie publiczne. Warszawa: Wydawnictwo Naukowe PWN; 2009. p. 90-102 (in Polish).

6. Bone mineral measurements and diagnosis of osteoporosis. In: WHO Scientific Group on the Assessment of Osteoporosis at Primary Health Care Level. Summary Meeting Report Brussels. WHO; 2004. p. 8.

7. Kłos A, Bertrandt J. Overweight and obesity occurence and estimation of mineral nutritional status of military medical aircraft crews. Lek. Wojsk. 2011; 89(2): 93-97 (in Polish).

8. Bertrandt J, Kłos A, Bertrandt B. Protein-energy and mineral nutritional status of soldiers serving in the Cavalry Squadron of the Polish Armed Forces Representative Battalion. 20th International Congress of Nutrition in Granada; 2013. p. 1433.

9. Bertrandt J, Kłos A, Łakomy R. Ocena uwapnienia kości żołnierzy polskich powracających z misji pełnionej w ramach Międzynarodowych Sił Wsparcia Bezpieczeństwa (ISAF) w Afganistanie, In: Kaiser A, Mrozkowiak M., editors. Zdrowotne i psychospołeczne aspekty służb mundurowych. Warszawa: Pol. Tow. Nauk. Kult. Fiz; 2013. p. 17-25 (in Polish).

10. Kłos A, Bertrandt J, Bieniek R, Kobos Z. Ocena stanu odżywienia oraz wydatku energetycznego związanego z treningiem kadry WP w skokach spadochronowych. Postępy Medycyny Lotniczej. 2006; 13: $183-189$ (in Polish).

11. Bertrandt J, Kłos A. Estimation of protein-energy and mineral nutritional status of flight engineers and navigators serving in the Polish Air Forces. Military Pharmacy and Medicine. 2012; 2: 118-121.

12. Kłos A, Bertrandt J, Łakomy R. Overweight and obesity occurrence as well as evaluation of bone calcification status of soldiers from one selected unit of the chemical troops. Probl. Hig. Epidemiol. 2012; 1 93(4): 844-847 (in Polish).

13. Compostan JE, Vedi S, Stephen AB, Bord S, Lyons AR, Hodges SJ, et al. Reduced bone formation in UK Gulf War Veterans: a bone histomorphometric study. J. Clin. Pathol. 2002; 55(12): 897-899.

14. Gam A, Goldstein L, Karmon Y, Minster I, Grotto I, Guri A, et al. Comparison of stress fractures of male and female recruits during basic training in the Israeli anti-aircraft forces. Mil. Med. 2005; 170(8): 710-712. 